\title{
Pengaruh Kebiasaan Membaca Dan Koleksi Buku Terhadap Prestasi Belajar Mahasiswa Stakpn Ambon
}

\author{
Krislina Pattipeiluhu \\ krislinapattipeiluhu05@gmail.com
}

\begin{abstract}
Education must produce quality human beings who are capable of facing global competition. Therefore, education institutions need to improve the quality of their graduates. In the development of education today both in developed countries and in developing countries, the interest in reading plays a significant role. Success in learning is largely supported by read interest. It is not enough that a study only exerts its power to listen and then memorize it, but it also has to be supported by many personal collections and library support books. By collecting books privately or being good library visitors and being able to use them well, chances are that one's learning achievements will increase. The high culture is fond of reading, resulting in increased interest in reading. The purpose of the study is to know the impact of the reading habits and collection of books on student learning achievements at the STAKPN campus Ambon. The influence of the reading and collection of books on STAKPN Ambon student learning Achievement in tests using existing regression, and begins with knowing the size of the variable donation habits (X1) and book Collection (X2) to variables Learning achievement $(Y)$ is seen that the value of $K P=57 \%$, meaning that the reading habits and books collection gave the contribution to the learning achievement of STAKPN Ambon students by 57\% and the remaining $43 \%$ is determined by other variables
\end{abstract}

Keyword: Reading habits, book collections, Learning Achievements

\section{Pengantar}

Globalisasi telah membawa dampak bagi segala aspek kehidupan, baik dalam bidang ekonomi, sosial, maupun budaya. Kondisi ini akan membawa persaingan yang semakin ketat dalam berbagai aspek kehidupan. Tantangan utama bagi bangsa Indonesia di era globalisasi adalah daya saing yang mengutamakan kamampuan Sumber Daya Manusia (SDM).

Berdasarkan laporan lembaga Human Development Report (HDR) tahun 2014, kualitas SDM Indonesia berada di urutan ke 121 dari 208 negara yang diteliti. Laporan tersebut menunjukkan bahwa kualitas SDM Indonesia tergolong rendah. Oleh karena itu bangsa Indonesia perlu berjuang dan mengupayakan untuk meningkatkan kualitas SDM. Salah satu upaya bangsa Indonesia meningkatkan kualitas SDM adalah melalui pendidikan.

Peningkatan kualitas SDM Indonesia, hanya dapat diperoleh melalui pendidikan. Karena pendidikan merupakan salah kunci untuk meningkatkan kualitas SDM Indonesia. Hanya melalui pendidikan tercipta manusia-manusia berkualitas yang nantinya akan mampu menghadapi persaingan global. Salah satu bentuk perhatian pemerintah terhadap pendidikan adalah dengan dituangkannya tujuan pendidikan nasional ke dalam Undang-Undang No. 20 Tahun 2003 tentang Sistem Pendidikan Nasional Bab II Pasal 3, yaitu Pendidikan Nasional berfungsi mengembangkan kemampuan dan membentuk watak serta peradaban bangsa yang bermartabat dalam rangka mencerdaskan kehidupan bangsa, bertujuan untuk berkembangnya potensi peserta didik agar menjadi manusia yang beriman dan bertakwa kepada Tuhan Yang Maha Esa, berakhlak mulia, sehat, berilmu, cakap, kreatif, mandiri, dan menjadi Warga Negara yang demoktratis serta bertanggung jawab.

Tujuan tersebut menunjukkan bahwa pendidikan mempunyai tugas dan tanggung jawab besar dalam menyiapkan generasi mendatang. Pendidikan harus menghasilkan manusia-manusia berkualitas yang mampu menghadapi persaingan global. Untuk itu lembaga pendidikan perlu meningkatkan kualitas para lulusannya. Baik lembaga pendidikan di tingkat dasar dan menengah maupun lembaga pendidikan tinggi. Dalam perkembangan pendidikan dewasa ini baik di negara maju mau pun di Negara yang sedang berkembang, minat membaca sangat memegang peranan penting. Keberhasilan dalam belajar sebagian besar ditunjang oleh minat baca. Seorang pelajar yang tidak berminat untuk membaca, mustahil belajarnya akan berhasil dengan baik.

Gie menyatakan bahwa "sebab tidak ada belajar yang dapat dilaksanakan tanpa pembacaan, dan gudang bacaan adalah perpustakaan". Tidaklah cukup seorang belajar hanya mengerahkan tenaganya untuk mendengarkan lalu menghafalkan saja, melainkan juga harus ditunjang banyak oleh buku-buku koleksi pribadi maupun dukungan perpustakaan (Gie, 1998). Dengan mengoleksi buku-buku secara pribadi maupun menjadi pengunjung perpustakaan yang baik dan dapat 
mempergunakannya dengan baik, kemungkinan besar prestasi belajar seseorang akan meningkat. Tingginya budaya gemar membaca, mengakibatkan meningkatnya minat membaca. Minat membaca di tunjukkan dengan keinginan yang kuat untuk melakukan kegiatan membaca. Sekarang ini banyak keluhan bahwa daya serap / pemahaman para pelajar dan mahasiswa terhadap penguasaan bahan ajar adalah rendah.

Penyebab rendahnya daya serap para pelajar dan mahasiswa terhadap bahan ajar tersebut bukan karena faktor potensial, tetapi salah satu penyebabnya yang penting adalah kebiasaan membaca buku yaitu pelajar dan mahasiswa yang mempunyai minat kebiasaan membaca bukunya lemah. Pelajar dan mahasiswa yang lebih banyak menggunakan waktunya untuk membaca akan memperoleh prestasi belajar yang lebih baik dibanding dengan yang tidak. Dengan adanya minat yang tinggi pada seseorang, akan menjadikannya lebih bersemangat dan bergairah dalam belajar. Seseorang yang tidak berminat untuk mempelajari sesuatu biasanya tidak dapat diharapkan akan berhasil dengan baik dalam menguasai ilmu yang dipelajari.

Sebaliknya kalau seseorang belajar atau membaca dengan penuh minat maka akan meluangkan waktunya yang cukup banyak untuk mendalami mata pelajaran tersebut sehingga diharapkan prestasi yang dicapai akan lebih baik. Dalam menghasilkan output yang berkualitas, maka dalam bidang pendidikan diperlukan upaya evaluasi pembelajaran yang memadai, untuk mengetahuikeber hasilan proses belajar seseorng dapat diketahui dari prestasi yang dicapainya.

Prestasi belajar merupakan pencerminan hasil belajar yang dicapai seseorang dalam melakukan proses belajar pada jenjang pendiidkan persekolahan maupun pada perguruan tinggi. Tinggi rendahnya prestasi belajar akan memberikan sumbangan dalam mencapai kesuksesan masa depan anak. Untuk mencapai prestasi belajar yang baik, seseorang dipengaruhi banyak faktor baik dari dalam maupun dari luar diri siswa tersebut. Dari dalam diri anak itu antara lain faktor kecerdasan, bakat, minat, motivasi, kesehatan jasmani dan juga usaha untuk meningkatkan prestasi, sedangkan dari luar anak meliputi lingkungan keluarga, sekolah, masyarakat, peralatan, dan media belajar.

Salah satu upaya untuk meningkatkan prestasi belajar pelajar dan mahasiswa yaitu dengan meningkatkan minat baca mereka dengan memiliki sejumlah buku yang sesuai dengan keinginan serta kebutuhan belajar. Selain minat baca, kebiasaan belajar diduga memiliki pengaruh yang besar dengan prestasi belajar yang dicapai pelajar dan mahasiswa. Setiap pelajar dan mahasiswa memiliki kebiasaan berbeda dalam membaca atau belajar. Ada pelajar dan mahasiswa yang teratur dalam membaca atau belajar, ada pelajar dan mahasiswa yang menunda mengerjakan tugas, ada pelajar dan mahasiswa yang asal-asalan dalam belajar, serta ada pelajar dan mahasiswa yang fokus dalam mengikuti pelajaran, dan sebagainya. Berkaitan dengan Kebiasaan membaca dan mengoleksi buku tersebut, hal ini juga dapat dilihat pada mahasiswa di Sekolah Tinggi Agama Kristen Protestan Negeri Ambon (STAKPN).

Berdasarkan informasi awal yang diperoleh dalam observasi awal diketahui bahwa kebiasaan membaca dan mengoleksi buku mahasiswa di Sekolah Tinggi Agama Kristen Protestan Negeri Ambon (STAKPN) saat ini sangatlah rendah. Informasi yang diperoleh bahwa ada mahasiswa belum mempunyai kemauan atau niat dalam membaca dan mengoleksi buku secara pribadi. Para mahasiswa yang dimintai pendapatnya tentang hal ini menyatakan bahwa tidak semestinya mengoleksi buku atau membiasakan untuk membaca, karena ilmu sudah diperoleh dari Dosen di kampus, dan itu sudah cukup.

Disisi lainnya yang terlihat adalah adanya pengaruh pergaulan, sehingga gaya hidup dan kebiasaan individu para mahasiswa menjadi lebih banyak memilih mengkonsumsi makanan atau berjajan bersama teman-temannya ketika berada diluar kampus ketimbang meluangkan banyak waktu untuk membaca dan mengoleksi buku. Saat di kampus mahasiswa jarang membaca ketika mata kuliah berlangsung, ada yang hanya membaca ketika dosen menyuruhnya, adapun yang tidak sama sekali meluangkan waktu untuk membaca di perpustakaan kecuali diberikan tugas oleh dosen barulah mahasiswa mengunjungi perpustakaan sebab mereka tidak memiliki buku pegangan sendiri. Ada mahasiswa yang menghabiskan waktu untuk memilih berbincang-bincang, mengotak-atik handphone atau gadget mereka (online di facebook, BBM, twitter,dan lain-lain), dan ketika di rumah atau kos, mereka bermain game di warnet-warnet atau membeli pulsa data untuk mengakses game melalui handphone ketimbang meluangkan banyak waktu untuk membaca dan sekaligus membeli dan mengoleksi buku secara pribadi.

Selain itu mahasiswa yang dimintai pendapatnya menyatakan bahwa mereka tidak 
menyediakan waktu untuk membaca buku ataupun mempelajari kembali materi-materi yang telah diberikan oleh dosen sehingga saat ujian mereka memperoleh nilai yang buruk serta tugas-tugas pun menumpuk. Dan sangat disayangkan adalah ketika disuruh membeli modul, banyak mahasiswa yang memberi jawaban tidak punya uang dan ketika tiba saat untuk ujian, banyak soal yang sebenarnya mudah tetapi tidak bisa di jawab, dan untuk menutupi kesalahan yang tidak disadari mahasiswa sering mengeluarkan argument yang negatif. Kecenderungan ini kemudian menjadi masalah serius karena imbasnya sangat dirasakan terhadap perkembangan kuliah mahasiswa.

Berdasarkan observasi awal yang penulis lakukan berkaitan dengan nilai KHS (Kartu Hasil Studi) Mahasiswa Tahun Akademik 2014/2015, diketahui bahwa nilai KHS mereka rendah, Indeks Prestasi hanya mencapai 2,55 dan hal ini sangat disayangkan karena akan berdampak pada penawaran mata kuliah semester berikutnya, artinya mereka akan dibatasi atau tidak dapat mengikuti mata kuliah yang seharusnya diperoleh pada semester berikutnya. Hasil nilai ini menunjukkan prestasi belajar mahasiswa Tahun Pelajaran 2014/2015 masih rendah. Kenyataan di atas, kenyataan di atas salah satu faktor penyebabnya adalah kebiasaan membaca serta mengoleksi buku tentunya akan berdampak terhadap prestasi belajar mahasiswa itu sendiri.

Berdasarkan uraian di atas, Maka Penulis merasa perlu melakukan penelitian dengan mengangkat judul "Pengaruh Kebiasaan Membaca dan Koleksi Buku Terhadap Prestasi Belajar Mahasiswa STAKPN Ambon”.

\section{Tinjauan Literatur \\ Minat atau Kebisaan Membaca}

Menurut Gie (2002) pengertiannya yang paling dasar, minat berarti sibuk, tertarik, atau terlihat sepenuhnya dengan sesuatu kegiatan karena menyadari pentingnya kegiatan itu. Minat menurut Ginting (2003) mempunyai arti kecenderungan hati (keinginan, kesukaan) terhadap sesuatu. Menurut Slameto (2003) minat adalah rasa lebih suka atau rasa keterikatan pada suatu hal atau aktivitas tanpa ada yang menyuruh. Sedang menurut Reber dalam Muhibbin (1995) mengemukakan bahwa minat tidak termasuk istilah populer dalam psikologi karena ketergantungannya yang banyak pada faktor-faktor internal lainnya seperti pemusatan perhatian, keingintahuan, motivasi dan kebutuhan. Secara sederhana minat (interest) berarti kecenderungan dan kegairahan yang tinggi atau keinginan yang besar terhadap sesuatu.

Minat pada dasarnya adalah penerimaan akan suatu hubungan antara diri sendiri dengan sesuatu di luar diri, semakin besar minat seseorang terhadap sesuatu perhatiannya lebih mudah tercurah pada hal tersebut. Minat yang besar terhadap sesuatu membuat seseorang mencurahkan banyak perhatiannya pada hal tersebut.

\section{Koleksi Buku}

Koleksi Buku terdiri dari dua kata, yakni "koleksi" dan "buku", mempunyai arti yang berbeda. Untuk memahami lebih jauh tentang pengertian koleksi buku, peneliti menjabarkan makna dari kedua kata tersebut. Koleksi adalah kumpulan bahan pustaka berdasarkan criteria tertentu. Semua bahan pustaka yang telah diorganisasikan, kemudian ditempatkan pada kelompok tertentu sesuai dengan jenisnya.

Koleksi juga merupakan kumpulan (gambar-gambar, benda-benda bersejarah, lukisan, dsb) yang sering dikaitkan dengan minat atau hobi. (KBBI:1993). Jadi dapat disimpulkan bahwa koleksi adalah kumpulan berbagai macam bentuk benda yang kemudian ditempatkan pada kelompok tertentu sesuai dengan jenisnya, karena itu merupakan suatu kesenangan/hobi.

Selanjutnya pengertian buku, untuk memahami pengertian tentang buku berikut dikemukakan pengertiannya antara lain : Buku merupakan ilmu. Buku itu menyimpan banyak informasi penting yang kita butuhkan, dengan banyak membaca buku maka seseorang akan banyak mengetahui segala sesuatu/ilmu. Buku bisa membuat seseorang mengetahui apa yang sebelumnya ia tidak ketahui. Buku juga dapat meningkatkan daya khayal/imajinasi . Dengan buku, bisa melihat sisi lain dari dunia yang ternyata bermacam-macam bentuknya. Oleh karena itu buku itu disebut dengan jendela dunia.

\section{Prestasi Belajar Siswa}

Menurut Tu'u (2004) bahwa "prestasi belajar adalah penguasaan pengetahuan atau ketrampilan yang dikembangkan oleh mata pelajaran, lazimnya ditunjukan dengan nilai tes atau angka nilai yang diberikan oleh guru".

Prestasi merupakan hasil yang dicapai seseorang ketika mengerjakan tugas atau kegiatan tertentu. Prestasi akademik adalah hasil belajar yang diperoleh dari kegiatan pembelajaran di sekolah atau di perguruan tinggi yang bersifat kognitif dan 
biasanya ditentukan melalui pengukuran dan penilaian. Sementara prestasi belajar adalah penguasaan pengetahuan atau ketrampilan yang dikembangkan oleh mata pelajaran, lazimnya ditunjukan dengan nilai tes atau angka nilai yang diberikan oleh guru.

\section{Metode}

Penelitian ini termasuk penelitian kuantitatif dengan pendekatan RegresiLinear Berganda, yaitu suatu pendekatan untuk mengetahui pengaruh lebih dari dua variabel bebas terhadap variabel terikat. Dalam penulisan ini yang menjadi variabel bebas terdiri dari variabel bebas pertama (XI) yakni Kebiasaan Membaca dan Variabel bebas kedua (X2) yaitu Koleksi Buku dengan variabel terikat $(Y)$ yakni Prestasi Belajar. Untuk mengetahui hubungannya, maka dalam perhitungan digunakan rumus regresi linear berganda menurut ridwan (2003), yaitu :

$$
\ddot{Y}=a_{0}+a_{1} b_{1} x_{1}+a_{2} b_{2} x_{2}
$$

Dimana :

$$
\widehat{Y}
$$

= (baca Y topi), Variabel terikat prestasi belajar

$a$ = bilangan konstanta

= koefisien kebiasaan membaca

$a_{1}=$ kebiasaan membaca

$a_{2}^{x_{1}}=$ koefisien koleksi buku

$x_{2}=$ koleksi buku

$b_{1}$ dan $b_{2}=$ nilai arah sebagai penentu ramalan (prediksi)

$b=$ nilai arah sebagai penentu ramalan (prediksi) yang menunjukan nilai peningkatan $(+)$ atau nilai penurunan (-) variabel $\mathrm{Y}$.

sedangkan nilai $a$ dan $b_{1}$ dan $b_{2}$ diperoleh dengan menggunakan rumus

$$
\begin{aligned}
& b_{1}=\frac{\left(\sum x_{2}^{2}\right)\left(\sum x_{1} y\right)-\left(\sum x_{1} x_{2}\right)\left(\sum x_{2} y_{2}\right)}{\left(\sum x_{1}^{2}\right)\left(\sum x_{2}^{2}\right)-\left(\sum x_{1} x_{2}\right)^{2}} \\
& a=\frac{\sum y}{n}-b_{1}\left(\frac{\sum x_{1}}{n}\right)-b_{2}\left(\frac{\sum x_{2}}{n}\right) \\
& b_{2}=\frac{\left(\sum x_{1}^{2}\right)\left(\sum x_{2} y\right)-\left(\sum x_{1} x_{2}\right)\left(\sum x_{1} y\right)}{\left(\sum x_{1}^{2}\right)\left(\sum x_{2}^{2}\right)-\left(\sum x_{1} x_{2}\right)^{2}}
\end{aligned}
$$

Sedangkan untuk menyatakan besar kecilnya sumbangan variabel $X$ terhadap variabel $Y$ dapat ditentukan dengan rumus koefisien determinan korelasi ganda sebagai berikut :

$$
\mathrm{KP}=\left(R_{x_{1} x_{2} x_{3} y}\right)^{2} \times 100 \%
$$

Dimana :

$$
\begin{array}{ll}
\text { KP } & \begin{array}{l}
\text { : Besarnya koefisien penentu } \\
\text { (determinan) }
\end{array} \\
\mathrm{r} & : \text { Koefisien korelasi }
\end{array}
$$

\section{Hasil dan Pembahasan}

Dari hasil pengumpulan data penelitian, penulis mendapatkan hasil tabukasi data sebagai berikut:

\section{Daftar Skor Kebiasaan Membaca (X1) dan Minat Belajar (X2) terhadap Prestasi Belajar (Y)}

\begin{tabular}{|c|c|c|c|c|}
\hline & \multirow{2}{*}{ Nama } & \multicolumn{3}{|c|}{$\begin{array}{c}\text { Nilai } \\
\text { Angket }\end{array}$} \\
\cline { 3 - 5 } No. & Kebiasaan & \multicolumn{2}{|c|}{$\begin{array}{c}\text { Minat } \\
\text { Belajar } \\
\text { (X2) }\end{array}$} & Prestasi \\
& & Melajar (Y) \\
\hline 1. & A.R.I & 63 & 62 & 3.48 \\
\hline 2. & J.J.M & 52 & 59 & 3.35 \\
\hline 3. & E. A. M & 52 & 55 & 3.57 \\
\hline 4. & I.S.N & 56 & 60 & 3.17 \\
\hline 5. & R.E & 68 & 57 & 3.04 \\
\hline 6. & M.L & 53 & 58 & 3.48 \\
\hline 7. & H.M.L & 57 & 59 & 3.43 \\
\hline 8. & C.M.W & 55 & 56 & 4 \\
\hline 9. & B.K & 51 & 45 & 2.48 \\
\hline 10. & S.S & 48 & 54 & 3.71 \\
\hline 11. & S.S.I & 50 & 47 & 3.93 \\
\hline 12. & R.M & 44 & 43 & 3.7 \\
\hline 13. & D.C.S & 57 & 52 & 3.74 \\
\hline 14. & L.H & 47 & 27 & 2.67 \\
\hline 15. & T.M & 64 & 63 & 3.52 \\
\hline 16. & S.D & 57 & 62 & 3.38 \\
\hline
\end{tabular}




\begin{tabular}{|c|c|c|c|c|}
17. & R.T & 42 & 38 & 3.51 \\
\hline 18. & F.M & 48 & 51 & 3.19 \\
\hline 19. & P.L & 50 & 48 & 3.3 \\
\hline 20. & R.A & 57 & 45 & 3.82 \\
\hline 21. & Y.M.B & 65 & 61 & 3.59 \\
\hline 22. & B.R.S & 53 & 51 & 3.62 \\
\hline 23. & N.S.M & 45 & 58 & 3.56 \\
\hline 24. & I.S & 34 & 30 & 3.45 \\
\hline 25. & I.F.S & 50 & 38 & 3.55 \\
\hline $26 .$. & L.M & 43 & 41 & 3.89 \\
\hline 27. & J.T & 44 & 56 & 3.22 \\
\hline 28. & J.R.R & 43 & 52 & 2.44 \\
\hline 29. & L.U & 37 & 27 & 2.58 \\
\hline 30. & A.S.G.G & 51 & 58 & 3.91 \\
\hline 31 & J.M & 50 & 63 & 3.84 \\
\hline 32 & D.T & 51 & 52 & 3.89 \\
\hline 33 & I.G.V.B & 39 & 51 & 3.89 \\
\hline 34 & J.S & 34 & 39 & 3.29 \\
\hline 35 & L.I.M & 46 & 46 & 3.59 \\
\hline 36 & Y.M & 55 & 65 & 3.48 \\
\hline & & & & \\
\hline
\end{tabular}

\section{- Analisis Pengaruh Kebiasaan Membaca Terhadap Prestasi Belajar Mahasiswa STAKPN Ambon.}

Berdasarkan hasil penelitian tersebut dapat dilihat bahwa sebelum melakukan proses analisa data, terlebih dahulu dilakukan uji validasi dan reliabilitas butir soal. Kemudian melakukan analisa regresi sederhana maka terdapat menunjukan persamaan regresi yakni ${ }^{\wedge}=20.10+0,76(X)$. Hal ini membuktikan terdapat garis linear artinya memiliki pengaruh X1 terhadap Y. Selain itu untuk memastikan apakah terdapat Pengaruh Kebiasaan Membaca Terhadap Prestasi Belajar Mahasiswa STAKPN Ambon di lihat pada nilai Fhitung yang dibandingkan dengan nilai Ftabel, maka diperoleh nilai Fhitung $=20,99$ dan Ftabel $=4,32$, sehingga dapat disimpulkan bahwa Ternyata Fhitung lebih besar dari Ftabel atau 20,99>4,32, maka H0 ditolak, artinya terdapat terdapat Pengaruh Kebiasaan Membaca Terhadap Prestasi Belajar Mahasiswa STAKPN Ambon.

\section{- Pengaruh Koleksi Buku Terhadap Prestasi Belajar Mahasiswa STAKPN Ambon}

Berdasarkan hasil penelitian tersebut dapat dilihat bahwa sebelum melakukan proses analisa data, terlebih dahulu dilakukan uji validasi dan reliabilitas butir soal. Kemudian melakukan analisa regresi sederhana maka terdapat menunjukan persamaan regresi yakni $=18.80+3,14(\mathrm{X})$. Hal ini membuktikan terdapat garis linear artinya memiliki pengaruh X2 terhadap Y. Selain itu untuk memastikan apakah terdapat Pengaruh Koleksi Buku Terhadap Prestasi Belajar Mahasiswa STAKPN Ambon di lihat pada nilai Fhitung yang dibandingkan dengan nilai Ftabel, maka diperoleh nilai Fhitung $=34,10$ dan Ftabel $=4,32$, sehingga dapat disimpulkan bahwa Ternyata Fhitung lebih besar dari Ftabel atau 34,10> 4,32, maka H0 ditolak, artinya terdapat Pengaruh Koleksi Buku Terhadap Prestasi Belajar Mahasiswa STAKPN Ambon.

\section{- Pengaruh Kebiasaan Membaca dan Koleksi Buku Terhadap Prestasi Belajar Mahasiswa STAKPN Ambon.}

Berdasarkan hasil penelitian tersebut dapat dilihat bahwa sebelum melakukan proses analisa data, terlebih dahulu dilakukan uji validasi dan reliabilitas butir soal. Kemudian dengan menggunakan koefisien korelasi (KP) untuk mengetahui besarnya sumbangan variabel kebiasaan membaca (X1) dan koleksi buku (X2) terhadap variabel prestasi belajar $(\mathrm{Y})$ terlihat bahwa nilai KP $=57 \%$, artinya Kebiasaan Membaca dan Koleksi Buku memberi konstribusi Terhadap Prestasi Belajar Mahasiswa STAKPN Ambon sebesar 57\% dan sisanya $43 \%$ ditentukan oleh variabel lain. Sedangkan untuk memastikan apakah terdapat Pengaruh Kebiasaan Membaca dan Koleksi Buku Terhadap Prestasi Belajar Mahasiswa STAKPN Ambon di lihat pada nilai Fhitung yang dibandingkan dengan nilai Ftabel, maka diperoleh nilai Fhitung $=21,35$ dan Ftabel $=3,28$, sehingga dapat disimpulkan bahwa Ternyata Fhitung lebih besar dari Ftabel atau 21,35>3.28, maka H0 ditolak, artinya terdapat Pengaruh Kebiasaan Membaca dan Koleksi Buku Terhadap Prestasi Belajar Mahasiswa STAKPN

\section{Simpulan}

Berdasarkan analisis data dan uji hipotesis tentangPengaruh Kebiasaan Membaca dan Koleksi Buku Terhadap Prestasi Belajar Mahasiswa STAKPN Ambon, maka dapat disimpulkan bahwa:

1. Untuk menguji hipotesis Pengaruh Kebiasaan Membaca Terhadap Prestasi Belajar Mahasiswa STAKPN Ambon menggunakan Analisa regresi sederhana maka terdapat menunjukan persamaan regresi yakni ${ }^{\wedge}=20.10+0,76(\mathrm{X})$. Selain itu untuk memastikan apakah terdapat Pengaruh 
Kebiasaan Membaca Terhadap Prestasi Belajar Mahasiswa STAKPN Ambon di lihat pada nilai Fhitung yang dibandingkan dengan nilai Ftabel, maka diperoleh nilai Fhitung= 20,99 dan Ftabel $=4,32$, sehingga dapat disimpulkan bahwa Ternyata Fhitung lebih besar dari ttabel atau 20,99 > 4,32, maka H0 ditolak, artinya terdapat Pengaruh Kebiasaan Membaca Terhadap Prestasi Belajar Mahasiswa STAKPN Ambon.

2. Untuk menguji hipotesis pengaruh Koleksi Buku Terhadap Prestasi Belajar Mahasiswa STAKPN Ambonmenggunakan Analisa regresi sederhana maka terdapat menunjukan persamaan regresi yakni ${ }^{\wedge}=18.80+3,14(\mathrm{X})$. Selain itu untuk memastikan apakah terdapat Pengaruh Koleksi Buku Terhadap Prestasi Belajar Mahasiswa STAKPN Ambon di lihat pada nilai Fhitung yang dibandingkan dengan nilai Ftabel, maka diperoleh nilai Fhitung $=34,10$ dan Ftabel $=4,32$, sehingga dapat disimpulkan bahwa Ternyata Fhitung lebih besar dari Ftabel atau 34,10> 4,32, maka H0 ditolak, artinya terdapat Pengaruh Koleksi Buku Terhadap Prestasi Belajar Mahasiswa STAKPN Ambon.

3. Pengaruh Kebiasaan Membaca dan Koleksi Buku Terhadap Prestasi Belajar Mahasiswa STAKPN Ambon di uji menggunakan regresi berganada, dan dimulai dengan mengetahui besarnya sumbangan variabel Kebiasaan Membaca (X1) dan Koleksi Buku (X2) terhadap variabel prestasi belajar (Y) terlihat bahwa nilai $\mathrm{KP}=57 \%$, artinya Kebiasaan Membaca dan Koleksi Buku memberi konstribusi Terhadap Prestasi Belajar Mahasiswa STAKPN Ambon sebesar 57\% dan sisanya $43 \%$ ditentukan oleh variabel lain. Sedangkan untuk memastikan apakah terdapat Pengaruh Kebiasaan Membaca dan Koleksi Buku Terhadap Prestasi Belajar Mahasiswa STAKPN Ambon di lihat pada nilai Fhitung yang dibandingkan dengan nilai Ftabel, maka diperoleh nilai Fhitung $=21,35$ dan Ftabel $=$ 3,28 , sehingga dapat disimpulkan bahwa Ternyata Fhitung lebih besar dari Ftabel atau 21,35> 3.28, maka H0 ditolak, artinya terdapat Pengaruh Kebiasaan Membaca dan Koleksi Buku Terhadap Prestasi Belajar Mahasiswa STAKPN Ambon.

\section{Saran}

Bertolak dari kesimpulan yang telah dipaparkan sebelumnya, maka penulis menyarankan kepada:

1. Para pengajar, khususnya para dosen agar dapat mendorong mahasisa dalam belajar, dengan mengoleksi buku-buku yang bermanfaat bagi proses pembelajaran di kampus, dan sekaligus membuat mahasiswa mencapai nilai maksimal dalam setiap akhir semester

2. Mahasiswa agar termotivasi untuk memiliki koleksi buku sesuai mata kuliah yang diikutinya serta membangun kebiasaan membaca baik di kampus maupun di luar kampus, dengan mengunjungi perpustakaanperpustakaan, toko buku, dll yang mampu membuatnya memiliki pengetahuan yang lebih baik berkaitan dengan proses perkuliahan.

\section{Ucapan Terima Kasih}

Penulis menyampaikan terima kasih kepada mahasiswa STAKPN Ambon yang telah membantu penulis untuk mengisi lembaran kuesioner untuk penulis dapat memperoleh data. Terima Kasih juga untuk Dosen STAKPN Ambon yang telah membantu penulis mengolah data hasil kuesioner, sehingga tulisan ilmiah ini bisa diselesaikan.

\section{Pustaka Acuan}

Arikunto, Suharsimi. (2002). Prosedur Penelitian Suatu Pendekatan Praktek. Cetakan Ke Dua Belas. Edisi Revisi V. Jakarta: Rineka Cipta

Gie, The Liang. (1998). Lintasan Sejarah Ilmu. Yogyakarta: Pusat Belajar lmu Berguna . (2002). Cara Belajar Yang Efisien Jilid II. Yogyakarta: PUBIB

Ginting, Cipta. (2003). Kiat Belajar Di Perguruan Tinggi. Jakarta: Grasindo

Hasan, Iqbal. (2004). Analisis Data Penelitian Dengan Statistik. Jakarta: Bumi Aksara.

KanisiusTarigan, Henry Guntur. (1998).Membaca Sebagai Ketrampilan Berbahasa.

Kartono, Kartini. (1990). Perananan Keluarga Berencana Memandu Anak. Jakarta: CV Rajawali

Marzuki, (200). Metodologi Riset . Yogyakarta: PT Prasetya Widia Pratama Muhidin dan Abdurahman. (2007). Analisis Korelasi, Regresi dan Jalur Dalam Penelitian.

Muhibbin, Syah,. (1995). Psikologi Pendidikan. Bandung: PT Rosdakarya 


\section{Krislina Pattipeiluhu}

Nurhadi. (2005). Membaca Cepat dan Efektif. Bandung: Sinar Baru Algesindo

Rahman,M. (1985). Strategi dan Langkah-Langkah Penelitian pendidikan. Semarang: IKIP Semarang

Ridwan. (2003). Dasar-dasar Statitika. Alfabeta:Bandung

Slameto. (2003). Belajar dan Faktor-faktor yang Mempengaruhinya. Jakarta:

Sudjana, Nana. (2008). Dasar-dasar Proses Belajar Mengajar, Bandung: Balai Pustaka.

Sumardji, P. (2003). Perpustakaan Organisasi dan Tata Kerjanya. Yogyakarta : 